\title{
Actual aspects of technique of growing pease in conditions of Northern Steppe of Ukraine
}

\author{
Gyrka A., Tkalich I., \\ Doctors of Agricultural Sciences \\ Sydorenko Yu., Bochevar O., llienko O. \\ Candidates of Agricultural Sciences \\ SI Institute of Grain Crops of NAAS of Ukraine
}

The purpose. To study effective elements of agrotechnique of growing pease which would ensure stability improvement of the crop to stressful ecological factors and simultaneous augmentation of productivity of grain. Methods. Generalization of results of long-term probes $(2011-2016)$ by systems analysis, field, laboratory, analytical, mathematical-and-statistical and settlement-relative methods. Results. Regularities of growth, development of plants of pease and formation of their grain productivity under the influence of application of traditional and innovative elements of agrotechnique of growing in conditions of climate fluctuations are justified. Conclusions. Model is designed of technique of growing highly productive sowings of pease with high adaptedness to stressful conditions of growing of Steppe of Ukraine which ensures stable development of economic valuable attributes of productivity and quality of grain with high indexes of economic and power efficiency.

Key words: pease, grade, growth regulators and biological preparations, seeding rate, fertilizers, structure of yield, grain, productivity.

Pea compared to cereals has a number of important benefits, especially in the output of valuable vegetable protein. In addition, growing peas in crop rotation significantly reduces the total cost of crop production, improves the phytosanitary state of crops and increases the productivity of arable land [1-3].

Peas distinguished from other legumes by the fact that the stem of the plant is not prone to branching and is growing predominantly in height. In favourable years, with excessive overgrowth of plants, sowings of peas strongly sinks, therefore, the need for two-phase harvesting is often required, which often leads to loss of yield [4-5]. In this regard, in the present situation, the priority direction of effective restoration of sown areas and increase of grain production of peas, should be the cultivation of high-yielding varieties of leafless morphological types with high potential productivity, resistance to stress factors of the environment, creeping and suitable for harvesting by direct harvesting [6-10]. That is why there is a need to improve the technology of cultivating pea varieties that are not prone to lodging in order to increase the yield of this crop.

In this regard, in the system of measures aimed at increasing the productivity of peas, the importance of rational use of fertilizers and seed rates is important.

The purpose of the research is to identify the peculiarities of the pea growth, development and grain production of leafless morphological type, depending on the norms of seed sowing and the application of mineral fertilizers.

Methods. Field experiments were carried out in grain-fallow-hoe farming crop rotation of the laboratory of agrobiological resources of spring cereals and legumes on the basis of Erastivka Experimental Station of the SI Institute of Grain Crops of the NAAS of Ukraine. The soil of experimental plots - ordinary chernozem, lowhumus and heavy-loamy. The content of humus in an arable layer of soil is $3,5-4,0 \%$, the $\mathrm{pH}$ of the water extract $-6,5-7,0$. Gross stocks of nutrients: nitrogen $-0,23-0,26 \%$, phosphorus $-0,11-0,16 \%$, potassium $2,0-2,5 \%$. Soil availability of mobile phosphorus forms can be characterized as close to the middle level, and potassium is relatively high.

Peas in field experiments were sown after winter wheat as predecessor. Mineral fertilizers (nitrophoska) were applied under pre-sowing cultivation according to experimental schemes. There were sown the pea varieties of different morphotypes, selected in leading breeding centers. 
Placement of variants in the field experiment is systematic in two tiers, with three replications, registration area of plot $-25 \mathrm{~m}^{2}$. Growing technology of pea in the experiment, except for studied measures, is generally accepted for the zone. The peas were planted with a $\mathrm{CH}-16$ seed drill, and the grain harvest was harvested by Sampo-500 combine harvester.

Results. In order to study the cumulative effect of environmental factors and identify the best varieties listed in the Register, in the laboratory annually conducted an ecological test of pea varieties (selected in leading breeding centers) by laying a demonstration experiment in which grain pea productivity was studied. Thus, on average, over the past six years (2011-2016), studies of the highest yield of grain provided varieties of leafless morphological type from The Plant Production Institute nd. a. V. Ya. Yuryev (Kharkivs'kyi etalonnyi, Kharkivs'kyi yantarnyi, Tsarevych, Deviz, Chekbek, Oplot, Otaman), The Plant Breeding and Genetics Institute - National Center of Seed and Cultivar Investigation (Svit, Odorus), Lugans'k Institute of agroindustry (Melior, Combainovyi 1) and foreign selection (Madonna, Mengir, Profit). The largest grain yield of peas $(3,10-3,70 \mathrm{t} / \mathrm{ha})$ was obtained in the crops of the varieties Tsarevych, Gliants, Kharkivs'kyi etalonnyi and Svit (Fig.).

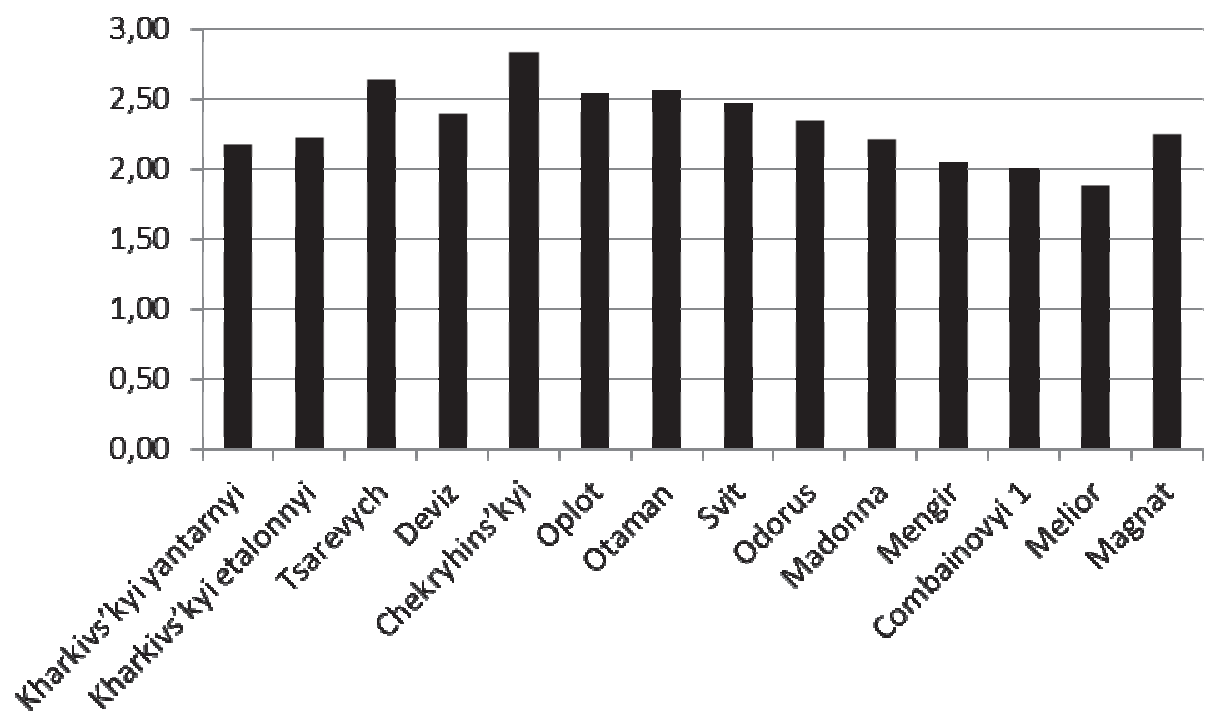

Grain yield of different varieties of pea, t/ha (average for 2011-2016)

Analysis of the structure of pea crop yield in the experiment showed that most pod grain content (3,0-3,4 pcs.) characterized plant varieties Tsarevych, Svit, Gliants, Deviz. The greatest weight of 1000 grains (229,5259,9 g) had varieties Oplot, Tsarevych, Chekryhins'kyi and Kharkivs'kyi etalonnyi.

Analysis of the economic efficiency of growing different varieties of peas showed that the highest profits in the experiment was obtained when growing varieties Tsarevych, Svit, Gliants. In this case, the lowest production costs per hectare and the cost of 1 ton of grain were obtained, and the level of profitability - the highest.

Researches on the effectiveness of thickening of crops and pre-planting seed treatment of peas variety Kharkivs'kyi etalonnyi by biological and humate-microelement preparations on two backgrounds of pre-plant fertilization - $\mathrm{N}_{15} \mathrm{P}_{15} \mathrm{~K}_{15}$ and $\mathrm{N}_{30} \mathrm{P}_{30} \mathrm{~K}_{30}$ (2011-2014) showed that the highest grain yield were obtained in variants at seeding with rate 1,4 million/ha and pre-planting seed treatment with ryzogumin and GK-A preparations.

In the experiment, where studied the optimal ratio of plants of different morphological types of peas (Kharkivs'kyi yantarnyi, Kharkivs'kyi etalonnyi) in crops on average for three years the higher grain yields obtained in single-species crops variety of conventional morphotype Kharkivs'kyi yantarnyi in the variant of seeding with rate 1,4 million /ha $-2,28$ t/ha (Table 1). 
1. Crop yield of peas depending on the percentage of varieties of different morphotypes and seed rate (2012-2014)

\begin{tabular}{|c|c|c|c|c|c|c|c|}
\hline \multirow{2}{*}{$\begin{array}{l}\text { Varia } \\
\text { nt }\end{array}$} & \multicolumn{2}{|c|}{ Proportion of seeeds mixture, $\%$} & \multirow{2}{*}{$\begin{array}{c}\text { Seed } \\
\text { rate, } \\
\text { million/ ha }\end{array}$} & \multicolumn{4}{|c|}{ Crop yield for years } \\
\hline & conventional pea & $\begin{array}{l}\text { leafless } \\
\text { pea }\end{array}$ & & $\begin{array}{l}201 \\
2\end{array}$ & $\begin{array}{l}201 \\
3\end{array}$ & $\begin{array}{l}201 \\
4\end{array}$ & $\begin{array}{l}\text { me } \\
\text { an }\end{array}$ \\
\hline 1 & 100 & 0 & & $\begin{array}{l}2,0 \\
6\end{array}$ & $\begin{array}{l}2,1 \\
1\end{array}$ & $\begin{array}{l}2,2 \\
7\end{array}$ & $\begin{array}{l}2,1 \\
5\end{array}$ \\
\hline 2 & 0 & 100 & & $\begin{array}{l}1,9 \\
3\end{array}$ & $\begin{array}{l}2,1 \\
0\end{array}$ & $\begin{array}{l}1,9 \\
2\end{array}$ & $\begin{array}{l}1,9 \\
8\end{array}$ \\
\hline 3 & 75 & 25 & 1,2 & $\begin{array}{l}1,9 \\
1\end{array}$ & $\begin{array}{l}2,0 \\
4\end{array}$ & $\begin{array}{l}2,2 \\
2\end{array}$ & $\begin{array}{l}2,0 \\
6\end{array}$ \\
\hline 4 & 50 & 50 & & $\begin{array}{l}1,9 \\
9\end{array}$ & $\begin{array}{l}2,1 \\
3\end{array}$ & $\begin{array}{l}2,2 \\
7\end{array}$ & $\begin{array}{l}2,1 \\
3\end{array}$ \\
\hline 5 & 25 & 75 & & $\begin{array}{l}1,9 \\
9\end{array}$ & $\begin{array}{l}2,0 \\
6\end{array}$ & $\begin{array}{l}2,0 \\
8\end{array}$ & $\begin{array}{l}2,0 \\
4\end{array}$ \\
\hline 6 & 100 & 0 & & $\begin{array}{l}2,0 \\
0\end{array}$ & $\begin{array}{l}2,1 \\
9\end{array}$ & $\begin{array}{l}2,6 \\
4\end{array}$ & $\begin{array}{l}2,2 \\
8\end{array}$ \\
\hline 7 & 0 & 100 & & $\begin{array}{l}2,0 \\
3\end{array}$ & $\begin{array}{l}2,1 \\
8\end{array}$ & $\begin{array}{l}2,1 \\
4\end{array}$ & $\begin{array}{l}2,1 \\
2\end{array}$ \\
\hline 8 & 75 & 25 & 1,4 & $\begin{array}{l}1,9 \\
5\end{array}$ & $\begin{array}{l}2,1 \\
1\end{array}$ & $\begin{array}{l}2,5 \\
8\end{array}$ & $\begin{array}{l}2,2 \\
1\end{array}$ \\
\hline 9 & 50 & 50 & & $\begin{array}{l}2,1 \\
0\end{array}$ & $\begin{array}{l}2,2 \\
0\end{array}$ & $\begin{array}{l}2,4 \\
2\end{array}$ & $\begin{array}{l}2,2 \\
4\end{array}$ \\
\hline 10 & 25 & 75 & & $\begin{array}{l}2,0 \\
2\end{array}$ & $\begin{array}{l}2,1 \\
7\end{array}$ & $\begin{array}{l}2,3 \\
5\end{array}$ & $\begin{array}{l}2,1 \\
8\end{array}$ \\
\hline 11 & 100 & 0 & & $\begin{array}{l}2,0 \\
4\end{array}$ & $\begin{array}{l}2,0 \\
8\end{array}$ & $\begin{array}{l}2,5 \\
1\end{array}$ & $\begin{array}{l}2,2 \\
1\end{array}$ \\
\hline 12 & 0 & 100 & & $\begin{array}{l}2,0 \\
3\end{array}$ & $\begin{array}{l}2,0 \\
6\end{array}$ & $\begin{array}{l}2,1 \\
5\end{array}$ & $\begin{array}{l}2,0 \\
8\end{array}$ \\
\hline 13 & 75 & 25 & 1,6 & $\begin{array}{l}1,9 \\
1\end{array}$ & $\begin{array}{l}2,0 \\
4\end{array}$ & $\begin{array}{l}2,2 \\
3\end{array}$ & $\begin{array}{l}2,0 \\
6\end{array}$ \\
\hline 14 & 50 & 50 & & $\begin{array}{l}1,8 \\
8\end{array}$ & $\begin{array}{l}2,0 \\
5\end{array}$ & $\begin{array}{l}2,3 \\
3\end{array}$ & $\begin{array}{l}2,0 \\
9\end{array}$ \\
\hline 15 & 25 & 75 & & $\begin{array}{l}1,8 \\
5\end{array}$ & $\begin{array}{l}1,9 \\
5\end{array}$ & $\begin{array}{l}2,1 \\
8\end{array}$ & $\begin{array}{l}1,9 \\
9\end{array}$ \\
\hline & $\mathrm{LSD}_{0,05 \text { tha }}$ for int & n of facto & & $\begin{array}{l}0,0 \\
4\end{array}$ & $\begin{array}{l}0,0 \\
7\end{array}$ & $\begin{array}{l}0,0 \\
9\end{array}$ & - \\
\hline
\end{tabular}

Slightly lower productivity $(2,21-2,24 \mathrm{t} / \mathrm{ha})$ formed crops with the same seeding rate, as well as a combination of seed mixtures of varieties Kharkivs'kyi yantarnyi and Kharkivs'kyi etalonnyi accordingly to the ratio of 75:25 and 50:50. In this case, the crops were fully suitable for direct harvesting. At sowing peas mostly with seeds of conventional morphological type, Kharkivs'kyi yantarnyi (75 and 100\%) crops were lodged and were unsuitable for direct harvesting.

Economic evaluation of pea growing efficiency shows that at sowing seed mixtures consists of 50 or $75 \%$ variety on leafless morphological type, formed non-lodging plants stand, suitable for direct harvesting, which significantly affects the reduction of losses of grain yield and saving costs for harvest work - from 613 to 694 $\mathrm{UAH} / \mathrm{ha}$. In variants with seed rate 1,2-1,4 million seeds per 1 ha at sowing with above said seed mixtures was received the cheapest and most cost-effective grain that provides a significant net profit.

The use of complex microelement growth regulators and biopreparations for pre-plant seeds treatment and plant feeding of peas by nutrients on different backgrounds mineral nutrition in 2012-2015 contributed increasing the crop yield to $0,10-0,56 \mathrm{t} / \mathrm{ha}$. The most effective proved the pre-plant seed treatment with 
preparations defens $\mathrm{C}+$ molybdenum chelate and spraying plants in budding phase by mixture of preparations molybdenum chelate + urea or antystres + molybdenum chelate + urea (Table 2 ).

2. Crop yield of pea variety Tsarevych depending on the seed treatment and spraying plants with microelement preparations, $t /$ ha (average for 2012-2015)

\begin{tabular}{|c|l|c|c|}
\hline SI. № & \multicolumn{1}{|c|}{ Variant } & Without fertilizers & $\mathrm{N}_{30} \mathrm{P}_{30} \mathrm{~K}_{30}$ \\
\hline 1. & control & 1,90 & 2,43 \\
\hline 2. & defens C - seed treatment & 2,00 & 2,47 \\
\hline 3. & Mo (molybdenum chelate) - seed treatment & 2,17 & 2,73 \\
\hline 4. & defens C + Mo (molybdenum chelate) - seed treatment & 2,12 & 2,60 \\
\hline 5. & urea (5\% solution) - spraying plants & 2,03 & 2,57 \\
\hline 6. & antystres - spraying plants & 1,98 & 2,41 \\
\hline 7. & antystres + urea (5\% solution) - spraying plants & 2,17 & 2,63 \\
\hline 8. & antystres + Mo (molybdenum chelate) - seed treatment & 2,68 \\
\hline 9. & $\begin{array}{l}\text { antystres + Mo (molybdenum chelate) + urea (5\% } \\
\text { solution) - spraying plants }\end{array}$ & 2,35 & 2,86 \\
\hline 10. & $\begin{array}{l}\text { defens C + Mo (molybdenum chelate) - seed treatment + } \\
\text { antystres + Mo (molybdenum chelate) + urea (5\% } \\
\text { solution) - spraying plants }\end{array}$ & 2,46 & 2,96 \\
\hline
\end{tabular}

The analysis of structural indicators in the experiment showed that the largest number of beans and grains on pea plants was formed in variants $7-8$, in comparison with control this exceeded, respectively, on the background without fertilizers for $0,3-0,5$ and 1,1-1,8 pcs., on background $\mathrm{N}_{30} \mathrm{P}_{30} \mathrm{~K}_{30}-0,1-0,3$ and $0,9-1,7$ pcs. Individual productivity of one plant in these variants, depending on the background of nutrition, was $1,77-2,23 \mathrm{~g}$ and increased comparatively to control - at 0,17-0,41 $\mathrm{g}$.

Determination the economic efficiency of the application of micronutrient preparations in the experiment shows that the highest profitability at the lowest cost of pea grains was observed in variants without fertilizer application. The application of mineral fertilizers with the dose $\mathrm{N}_{30} \mathrm{P}_{30} \mathrm{~K}_{30}$ led to an increase in production costs by 1903-1960 UAH/ha, the cost of grain - by 143-239 UAH/ton and a decrease in profitability - by 6,3$11,7 \%$. When using microelement preparations in pea growing technology costs increased, however, in comparison with the control options, the cost of grain decreased and increased profitability: on the background without fertilizers - for 17-299 $\mathrm{UAH} / \mathrm{t}$ and $0,8-14,9 \%$, on the background of application $\mathrm{N}_{30} \mathrm{P}_{30} \mathrm{~K}_{30}$ - for 31-251 UAH/t and 1,3-11,2\% respectively.

Thus, as a result of multi-year experimental field and laboratory studies were found a set of interrelated effective agrotechnological measures, namely: the selection of the best varieties for single-species seed mixtures of various morphotypes of peas; use reasonable seeding rates, doses, methods and timing of application the mineral fertilizers, plant growth regulators, micronutrients and biopreparations that form the pattern of cultivation, which is characterized by high adaptability of crops to stressful growing conditions of Steppe Ukraine, provides stable expression of economically valuable traits in crop yield and grain quality with high rates of economic and energy efficiency.

\section{Conclusions}

The most productive in some years were pea varieties: Tsarevych $-3,71 \mathrm{t} / \mathrm{ha}$, Gliants $-3,25$, Kharkivs'kyi etalonnyi - 3,06 (PPI. nd. a. V. Ya. Yuriev) and Svit $-3,38 \mathrm{t} / \mathrm{ha}(\mathrm{PB} \& \mathrm{GI}-\mathrm{NCSCl})$. On average, for the six years (2011-2016), the highest grain yield of peas $(2,54-2,83 \mathrm{t} / \mathrm{ha})$ was obtained in the varieties Oplot, Otaman, Tsarevych, Chekrygins'kyi.

The optimum seeding rate of leafless pea morphological type variety Kharkivs'kyi etalonnyi on the background of fertilization with $\mathrm{N}_{15} \mathrm{P}_{15} \mathrm{~K}_{15}$ and $\mathrm{N}_{30} \mathrm{P}_{30} \mathrm{~K}_{30}$ (2011-2014) was set 1,4 million /ha. Pre-sowing seed treatment with ryzogumin or humate-microelement preparation GK-A contributed to an increase in crop yield by $11,3-13,3 \%$. 
The most effective proved sowing peas with seeding rate 1,4 million/ha of variety Kharkivs'kyi yantarnyi with $100 \%$ composition of seeds $(2,28 \mathrm{t} / \mathrm{ha}$ ) or using seeds of conventional variety morphotype (Kharkivs'kyi yantarnyi) and leafless (Kharkivs'kyi etalonnyi) in a mixture of $75: 25 \%(2,21-2,24 \mathrm{t} / \mathrm{ha})$. The crops of these variants were completely suitable for direct harvesting.

Application of complex micronutrient preparations on different backgrounds of mineral fertilizers contributed to increase of the stability of peas and grain yield of culture for 0,10-0,56 $t /$ ha. The most effective proved pre-plant seed treatment with preparations: defens $C+$ molybdenum chelate and spraying at budding phase with mixture of preparations - molybdenum chelate + urea or antystres + molybdenum chelate + urea.

\section{Bibliography}

1. Naukovi osnovy ahropromyslovoho vyrobnytstva $v$ zoni Stepu Urkainy / M.V. Zubets (holova red. kolehii) ta inshi. Kyiv: Ahrarna nauka, 2010. $986 \mathrm{s.}$

2. Kulyk L.A. (1997). Rezultatы y napravlenyia selektsyy zernovыkh, zernobobovыkh y krupiandkh kultur na opыtnыkh stantsyiakh Ynstytuta sakharnoi sveklы. Udoskonalennia metodiv selektsii ta nasinnytstva zernovykh, zernobobovykh i krupianykh kultur. Kyiv. S. 8-13.

3. Dmytrenko P.O., Vytrykhovskyi P.I. (1975). Udobrennia ta hustota posivu polovykh kultur. Kyiv: Urozhai. $248 \mathrm{~s}$.

4. Zhang L., Garneau M.G., Majumdar R. and other (2015). Improvement of pea biomass and seed productivity by simultaneous increase of phloem and embryo loading with amino acids. Plant Journal. Jan; №81(1). P. 134-146.

5. Savranchuk V.V., Ishchenko V.A. (2015). Vplyv bakterialnykh i biolohichno aktyvnykh preparativ na formuvannia produktyvnosti roslynamy horokhu vusatoho typu v Pivnichnomu Stepu. Biul. ISHSZ NAAN Ukrainy. № 6. S. 119-125.

6. Babych A.O. (1993). Problema bilka i vyroshchuvannia zernobobovykh na korm. Kyiv: Urozhai. $152 \mathrm{~s}$.

7. Reckling M., Hecker J. M., Bergkvist G. and other (2016). A cropping system assessment framework Evaluating effects of introducing legumes into crop rotations. European Journal of Agronomy. Vol. 76. P. 186-197.

8. Zuza V. (2016). Horokh bez burianiv. The Ukrainian FARMER. March. S. 100-102.

9. Preissel S., Reckling M., Schläfke N., Zander P. (2015). Magnitude and farm-economic value of grain legume pre-crop benefits in Europa. Field Crop Research. Vol. 175. №1. P. 64-79.

10. Cherenkov A.V., Klysha A.I., Hyrka A.D., Kulinich O.O. (2014). Zernobobovi kultury: suchasni tekhnolohii vyroshchuvannia. Monohrafiia; za red. A.V. Cherenkova. Dnipropetrovsk: «Aktsent PP», 2014. $110 \mathrm{~s}$. 